\title{
Spatial distribution of genetic diversity in popula- tions of Hagenia abyssinica (Bruce) J.F. Gmel from Ethiopia
}

\author{
T.B. Ayele, O. Gailing, R. Finkeldey
}

Ayele T.B., Gailing O., Finkeldey R., 2017. Spatial distribution of genetic diversity in populations of Hagenia abyssinica (Bruce) J.F. Gmel from Ethiopia. Ann. For. Res. 60(1):

Abstract. Genetic variation among 596 individuals from 22 natural and 3 planted populations of Hagenia abysinica (Rosaceae) sampled from the montane forests of Ethiopia was investigated at amplified fragment length polymorphism (AFLP) loci. We observed 106 unequivocally scorable AFLP markers out of which 91.5 percent were polymorphic. Populations harbored varying genetic diversities $\left(H_{e}=0.139-0.362\right)$, and showed low but significant genetic differentiation among them $\left(F_{S T}=0.077\right)$. Significant differentiation was observed even though previous paleoecological studies indicated that Hagenia abysinica recolonized Ethiopia only after the Last Glacial Maximum, and our earlier analyses of maternally inherited chloroplast DNA revealed low mixing of recolonizing lineages through seeds and rare long distance seed dispersal. Genetic diversity did not decrease along recolonization routes, confirming effective gene flow, most likely through pollen, among populations. The observed variation at putatively neutral AFLPs does not reflect clinal variation patterns. As expected, population differentiation is lower at anonymous, mostly biparentally inherited, AFLPs than at maternally inherited chloroplast haplotypes. Despite presumably efficient seed and pollen dispersal of $H$. abysinica by wind, a significant non-random fine-scale spatial genetic structure was observed up to $80 \mathrm{~m}$ in some populations. Due to significant pair-wise differentiation observed between populations, as many populations as possible should be considered for conservation, tree improvement and forestation programs. Keywords AFLPs, genetic diversity, kinship coefficient, population differentiation, recolonization, spatial genetic structure

Authors. Taye Bekele Ayele (Taye.Ayele@gov.bc.ca) - Ministry of Forests, Lands and Natural Resource Operations, 205 Industrial Rd. G. Cranbrook, BC V1C 7G5, Canada; Oliver Gailing - School of Forest Resources and Environmental Science, Michigan Technological University, Houghton, MI 49931, United States; Reiner Finkeldey - University of Kassel, Mönchebergstraße 19, 34125 Kassel, Germany.

Manuscript received August 17, 2016; revised February 3, 2017; accepted February 17, 2017; online first February 22, 2017. 


\section{Introduction}

Patterns of genetic diversity are affected by evolutionary processes and life history traits that collectively define the population's genetic structure (e.g., Yeh 2000). Tree species are generally characterized by high levels of genetic diversity within populations and relatively low levels of differentiation among populations (Loveless \& Hamrick 1984, Finkeldey \& Hattemer 2007, White et al. 2007). The geographic variation of genetic diversity has important implications for the ecological (e.g., adaptation to changing environmental conditions) and evolutionary (e.g., speciation) potential of populations (e.g., Hoffmann \& Blows 1994) and for the conservation and use of genetic resources (e.g., Bawa \& Krugman 1990). Genetic diversity is rarely distributed homogeneously within populations and genetic similarity is often higher among neighboring than among distant individuals (Vekemans \& Hardy 2004; Jump \& Peñuelas 2007). Such fine-scale genetic structure is affected by the dispersal ability, the mating system (higher in selfing species), life form (higher in herbs than trees) and population density (higher under low density) of a species (Vekemans \& Hardy 2004, Cavers et al. 2005, Jump \& Peñuelas 2007, Hardy et al. 2006).

Several studies on colonization history detected a decreasing genetic diversity with increasing distance from refugial sources based on contemporary patterns of genetic diversity (Rivera-Ocasio et al. 2002; Coart et al. 2005; Kebede et al. 2007). The decrease of genetic diversity during colonization is due to successive founder events and possibly further reduced by drift due to the small size of new populations (Wright 1969, Nei 1987, Rivera-Ocasio et al. 2002). Contrarily, other studies reported higher genetic diversity away from source populations due to gene flow and population admixture effects (e.g., Comps et al. 2001, Petit et al. 2003).

Hedberg (1989) and Negash (1995) reported that Hagenia abyssinica (Bruce) J.F. Gmel. is a predominantly wind-pollinated and wind-dispersed broad-leaved dioecious tree species belonging to a monotypic genus in the Rosaceae family. Nonetheless, the bright colourful and appealing appearance of the flowers of $H$. abyssinica (Supporting Information 2) is not typical for wind-pollinated species, suggesting that other pollinating vectors such as insects (particularly bees) might be involved in pollination. This view is supported by reports of honeybees collecting pollen from the male flowers and nectar from the female flowers (Fichtl \& Admasu 1994). Diaspores are very light (weight of 1000 seeds: $2.2 \mathrm{~g}$ ) and can easily be dispersed by wind. The species is found in 12 countries in Africa stretching from Ethiopia in the North to Zimbabwe in the South and inland to Congo (Hedberg 1989). It grows within an altitudinal range of 1,850 to 3,700 $\mathrm{m}$ asl (Hedeberg 1989, Friis 1992, Azene et al. 1993, Negash 1995) inhabiting the montane forests, montane woodlands and montane grasslands. The extant Hagenia populations throughout Ethiopia are situated at higher altitudes, often in wetter depressions (Ayele et al. 2009). Lange, Bussmann, \& Beck (1997) reported that the regeneration capability of $H$. abyssinica was limited by herbivores. Hagenia abyssinica is a multipurpose tree species bestowed with considerable economic and ecological values. It is one of the best timber species in Ethiopia preferred for its strength, fine texture and attractive appearance. A concoction made from the powder of dried female inflorescences is used as a purgative and taenicide against tapeworm in Ethiopia (see Ayele et al. 2011 and the references therein). But due to over-exploitation, the species is gravely endangered in its natural range particularly in Ethiopia (Negash 1995) with only about 7000 individuals left in the wild (Ayele et al. 2011). Ayele et al. (2009) inferred that H. abyssinica recolonized Ethiopia in the late Pleistocene (since 16,700 years before present) from southern African countries based on evaluation of fossil pollen records (Beuning et al. 
1997, Bonnefille et al. 1995, Olago et al. 1999, Umer et al. 2007). A recent phylogeographic investigation using maternally inherited chloroplast markers supported the recolonization hypothesis and suggested a single entry point into Ethiopia (Ayele et al. 2009). The recolonization route of the species was reconstructed, and rare mutation and long distance seed dispersal events were identified. A very high population differentiation $\left(\mathrm{N}_{\mathrm{ST}}=0.926\right)$ was reported whilst six haplotypes, which were grouped in two lineages, were identified (Ayele et al. 2009). The genetic diversity of few populations of $H$. abyssinica was investigated by RAPD (Kumilign 2005) and ISSR (Feyissa 2007) markers. Both studies covered a small spatial scale contrasting to the widespread natural distribution of the species in Ethiopia, and were also limited to small numbers of individuals per population.

In the present study, we cover the whole natural distribution range of $H$. abyssinica in Ethiopia to examine: 1) genetic diversity within and among populations, 2) changes in genetic diversity of the species along its recolonization routes, and 3) fine-scale spatial genetic structure. Based on various studies and arguments presented above, and the fact that $H$. abyssinica is an obligatorily outcrossing dioecious species with wind-induced seed and pollen dispersal, we developed the following three hypotheses for each of the objectives: (1) Genetic diversity is high within and low among populations; (2) genetic diversity is not correlated with population size and is not lost along recolonization routes; (3) no significant fine-scale spatial genetic structure is observed within populations.

\section{Materials and methods}

\section{Sampling and DNA isolation}

Twenty two naturally regenerated and three planted populations were surveyed from all re- gions where $H$. abyssinica is known to grow in Ethiopia (Fig. 1). A sampling spot was chosen at random from each of the naturally regenerated and planted populations. Twenty-three to twenty-four contiguous individuals per populations were sampled to allow the analyses of spatial genetic structure, particularly in the natural populations. The naturally regenerated populations represent twelve closed forest, eight woodland and two farmland ecosystems (Table 1). The planted populations were $2-15$ years old and the seed sources for two of them (DKP and SMP, see Table 1) were known and among the 22 sampled natural populations. The sizes of the sampled naturally regenerated trees range from $3 \mathrm{~m}$ to $35 \mathrm{~m}$ in height and from $2.5 \mathrm{~cm}$ to $245 \mathrm{~cm}$ in diameter at breast height $(\mathrm{DBH})$. The distances between trees within the same natural population range from $0.1 \mathrm{~m}$ to $730 \mathrm{~m}$. The densities of the populations range from 0.7 to 75.7 and 1416 to 1912 individuals/ha for naturally regenerated and the planted populations, respectively (Table 1). Total population sizes were estimated for the natural populations by counting all trees with DBH above $2.5 \mathrm{~cm}$.

Young leaves were collected, partially desiccated in paper bags before drying with silica gel and stored at room temperature until DNA isolation. The geographic coordinates of all the trees were recorded by using Garmin GPS®. Sexes of trees were identified only for those twelve populations with flowering trees at the time of the survey (Table 1). These data are used to compare genetic diversities between the two sexes. Genomic DNA was isolated from approximately $1 \mathrm{~cm}^{2}$ (ca. $20 \mathrm{mg}$ ) leaf materials following the DNeasy 96 kit protocol of Qiagen ${ }^{\circledR}$ (Hilden, Germany).

\section{DNA restriction, PCR amplification and geno- typing}

The amplified fragment length polymorphism (AFLP) technique was employed to investigate patterns of genetic diversity, population differ- 


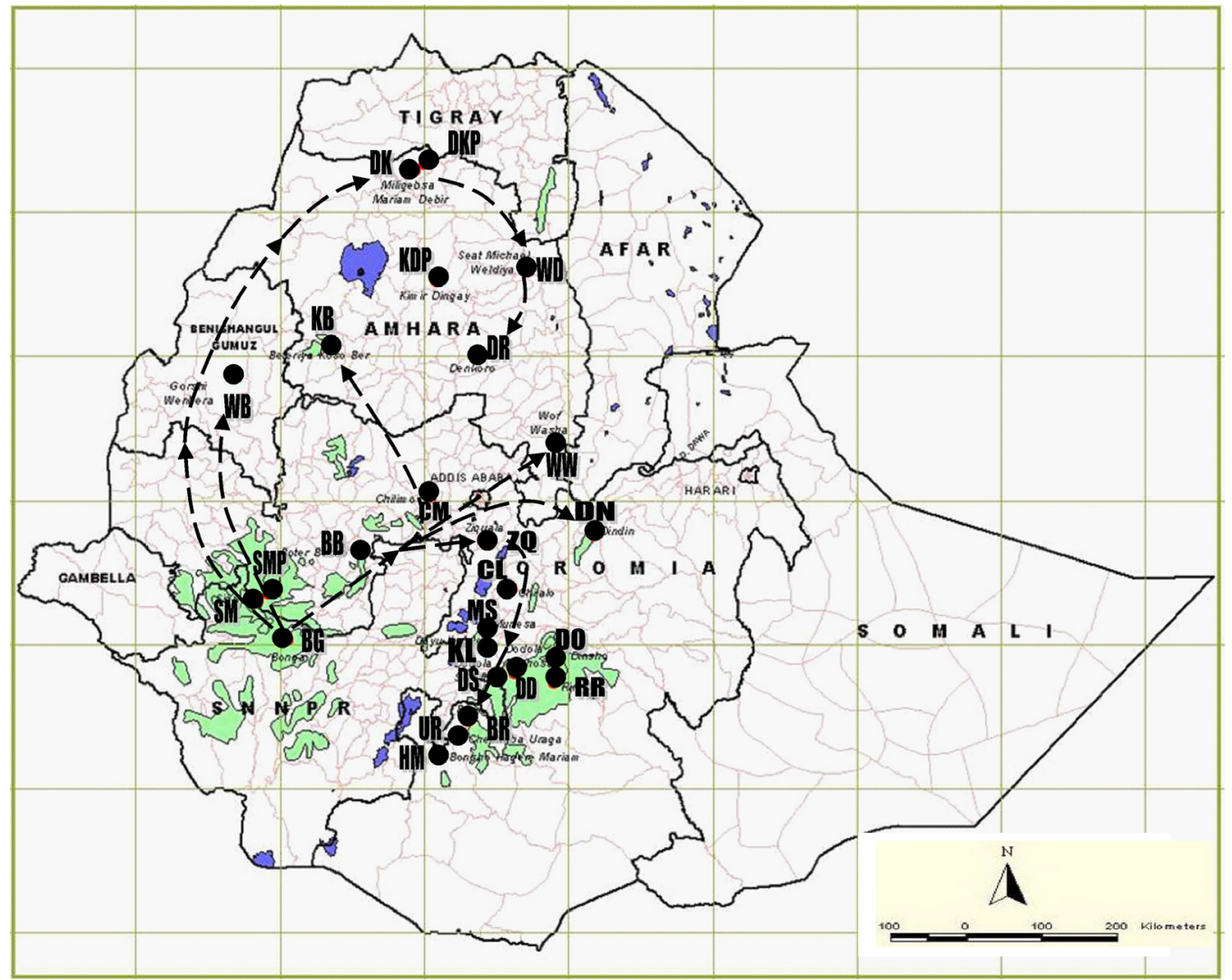

Figure 1 Distribution of $H$. abyssinica populations sampled from Ethiopia, represented by solid circles. Codes of populations follow Table 1. Broken lines with arrows indicate the putative recolonization route of $H$. abyssinica starting from the most likely source population BG as deduced from cpDNA analysis (Ayele et al. 2009). Shaded areas show extant closed forests. Source map: Assefa G (unpublished).

entiation and fine-scale spatial genetic structure in natural and some planted populations of Hagenia abyssinica (Bruce) J.F. Gmel from Ethiopia. The AFLP technique was chosen because of its cost-effective generation of data from a large number of loci distributed randomly across the genome and the ease to generate anonymous multilocus DNA profiles regardless of origin or complexity without prior sequence knowledge of the target species (Vos et al. 1995). AFLP has been used in various genetic studies; for example, genetic diversity (Cao et al. 2006), hybridization (Vasilyeva \& Semerikov 2014), homoplasy (Vekemans et al.
2002), and molecular mapping studies (Ekramoddoullah \& Liu 2008).

The laboratory protocol followed Vos et al. (1995) with some modifications. Genomic DNA was digested with two different restriction enzymes, a rare-cutter (EcoRI; 5'-G $\downarrow$ AATTC-3') and a frequent-cutter (MseI; 5'-T $\downarrow$ TAA-3'), and short DNA fragments (adapters) were ligated to cohesive ends of the restriction fragments. Four $\mu$ genomic DNA (about $10 \mathrm{ng}$ ) were added to $6 \mu \mathrm{l}$ restriction-ligation reaction containing $1 \mu \mathrm{l}$ T4-Ligase buffer (10x), $1 \mu \mathrm{l} \mathrm{NaCl}$ (0.5 M), 0.5 $\mu \mathrm{l} \mathrm{BSA} \mathrm{(1}$ $\mathrm{mg} / \mathrm{ml}), 3 \mu \mathrm{l} \mathrm{M} \pm$ Adapter $(5 \mathrm{pmol} / \mu \mathrm{l}), 0.6 \mathrm{E} \pm$ 
Table 1 Description of $H$. abyssinica populations sampled from the mountains of Ethiopia

\begin{tabular}{|c|c|c|c|c|c|c|c|c|c|c|c|c|}
\hline $\begin{array}{l}\text { Popula- } \\
\text { tions }\end{array}$ & Code & $\begin{array}{l}\text { Lati- } \\
\text { tude }\end{array}$ & $\begin{array}{l}\text { Longi- } \\
\text { tude }\end{array}$ & $\begin{array}{l}\text { Alti- } \\
\text { tude } \\
\left(\mathrm{m} \mathrm{asl}{ }^{\mathrm{a}}\right)\end{array}$ & $\begin{array}{l}\mathrm{ARF}^{\mathrm{b}} \\
\left(\mathrm{ml}^{\mathrm{c}}\right)\end{array}$ & $\begin{array}{l}\text { Min } \\
T^{d}\end{array}$ & $\begin{array}{l}\text { Max } \\
\mathrm{T}^{\mathrm{e}}\end{array}$ & $\mathrm{H}^{\mathrm{f}}$ & $n^{g}$ & $\mathrm{~N}^{\mathrm{h}}$ & $\begin{array}{l}\text { Density } \\
\text { (ind/ha) }\end{array}$ & $\begin{array}{l}* \text { Sex } \\
\text { index }\end{array}$ \\
\hline $\begin{array}{l}\text { Debark- } \\
\text { Mariam }\end{array}$ & DK & $13^{\circ} 11^{\prime}$ & $37^{\circ} 57^{\prime}$ & 3013 & 1270 & 8.8 & 19.7 & 4 & 24 & 26 & 16 & 1 \\
\hline $\begin{array}{l}\text { Debark- } \\
\text { Plantation }\end{array}$ & DKP & $13^{\circ} 12^{\prime}$ & $38^{\circ} 01^{\prime}$ & 3005 & 1270 & 8.8 & 19.7 & 4 & 24 & - & & NA \\
\hline $\begin{array}{l}\text { Kimir- } \\
\text { Dingay } \\
\text { plantation }\end{array}$ & KDP & $11^{\circ} 48^{\prime}$ & $38^{\circ} 14^{\prime}$ & - & 1350 & 9.2 & 21.9 & 1,6 & 24 & - & & NA \\
\hline $\begin{array}{l}\text { Woldiya } \\
\text { Se'at } \\
\text { Michael }\end{array}$ & WD & $11^{\circ} 55^{\prime}$ & $39^{\circ} 24^{\prime}$ & 3112 & 908 & NA & NA & 6 & 24 & 120 & & NA \\
\hline Kosso-ber & KB & $10^{\circ} 59^{\prime}$ & $36^{\circ} 54^{\prime}$ & 2702 & 2381 & 12.9 & 27.4 & 1 & 24 & 60 & 52 & NA \\
\hline Denkoro & DR & $10^{\circ} 52^{\prime}$ & $38^{\circ} 47^{\prime}$ & 3061 & 896 & 10.9 & 21.8 & 6 & 24 & 60 & 12.5 & 0.7 \\
\hline Wonbera & WB & $10^{\circ} 34^{\prime}$ & $35^{\circ} 41^{\prime}$ & 2428 & 1622 & NA & NA & 5 & 24 & 60 & 75.7 & NA \\
\hline Wof-washa & WW & $09^{\circ} 45^{\prime}$ & $39^{\circ} 44^{\prime}$ & 3159 & 941 & 6.1 & 19.9 & 1 & 24 & 45 & 5.4 & NA \\
\hline Chilimo & $\mathrm{CM}$ & $09^{\circ} 05^{\prime}$ & $38^{\circ} 10^{\prime}$ & 2805 & 1114 & 11.5 & 25.8 & 1,4 & 24 & 65 & 17.8 & $\mathrm{NA}$ \\
\hline Dindin & $\mathrm{DN}$ & $08^{\circ} 36^{\prime}$ & $40^{\circ} 14^{\prime}$ & 2410 & 989 & 12.7 & 28,0 & 1 & 24 & 55 & 13.9 & NA \\
\hline $\begin{array}{l}\text { Zequala } \\
\text { Abo }\end{array}$ & ZQ & $08^{\circ} 32^{\prime}$ & $38^{\circ} 50^{\prime}$ & 2856 & 1215 & NA & NA & 1 & 23 & 60 & 0.7 & 0.3 \\
\hline $\begin{array}{l}\text { Boter- } \\
\text { becho }\end{array}$ & BB & $08^{\circ} 24^{\prime}$ & $37^{\circ} 15^{\prime}$ & 2772 & 1666 & 5.7 & 23.6 & 1 & 24 & 60 & 27.8 & 1.2 \\
\hline Chilalo & $\mathrm{CL}$ & $07^{\circ} 56^{\prime}$ & $39^{\circ} 11^{\prime}$ & 2815 & 796 & 9.8 & 23,0 & 1 & 24 & 70 & 7.1 & 1.8 \\
\hline $\begin{array}{l}\text { Sigmo } \\
\text { plantation }\end{array}$ & SMP & $07^{\circ} 55^{\prime}$ & $36^{\circ} 10^{\prime}$ & 2300 & 1837 & 11.4 & 21.6 & 4 & 24 & - & & NA \\
\hline Sigmo & SM & $07^{\circ} 46^{\prime}$ & $36^{\circ} 05^{\prime}$ & 2651 & 1837 & 11.4 & 21.6 & 4 & 23 & 60 & 23.8 & NA \\
\hline Munesa & MS & $07^{\circ} 25^{\prime}$ & $38^{\circ} 53^{\prime}$ & 2459 & 1028 & 10.1 & 24.3 & 1 & 24 & 80 & 10 & NA \\
\hline Bonga & BG & $07^{\circ} 17^{\prime}$ & $36^{\circ} 22^{\prime}$ & 2238 & 2217 & 11.9 & 26.6 & 4 & 24 & 80 & 5 & 0.9 \\
\hline Kofele & $\mathrm{KL}$ & $07^{\circ} 11^{\prime}$ & $38^{\circ} 52^{\prime}$ & 2757 & 1305 & 7.7 & 20.1 & $1,2,3$ & 24 & 110 & 12.5 & 1.8 \\
\hline Dinsho & $\mathrm{DO}$ & $07^{\circ} 05^{\prime}$ & $39^{\circ} 47^{\prime}$ & 3117 & 1213 & 3.4 & 20.8 & 2 & 24 & 260 & 16.7 & 3 \\
\hline $\begin{array}{l}\text { Doddola- } \\
\text { Serofta }\end{array}$ & DS & $06^{\circ} 52^{\prime}$ & $39^{\circ} 02^{\prime}$ & 2700 & 1074 & 6.7 & 24.3 & 2 & 23 & 75 & 10 & 2.9 \\
\hline $\begin{array}{l}\text { Doddola- } \\
\text { Dachosa }\end{array}$ & DD & $06^{\circ} 52^{\prime}$ & $39^{\circ} 14^{\prime}$ & 3039 & 1074 & 6.7 & 24.3 & 2 & 24 & 5000 & 30.9 & NA \\
\hline Rira & RR & $06^{\circ} 45^{\prime}$ & $39^{\circ} 43^{\prime}$ & 2725 & 736 & NA & NA & 2 & 23 & 170 & 10.5 & NA \\
\hline Bore & BR & $06^{\circ} 17^{\prime}$ & $38^{\circ} 39^{\prime}$ & 2631 & 1526 & 8.3 & 18.8 & $1,2,3$ & 24 & 100 & 9.1 & 1.1 \\
\hline Uraga & UR & $06^{\circ} 08^{\prime}$ & $38^{\circ} 33^{\prime}$ & 2508 & 1228 & 8.3 & 18.8 & 2,3 & 24 & 70 & 13.9 & 0.7 \\
\hline $\begin{array}{l}\text { Hagere } \\
\text { Mariam }\end{array}$ & HM & $05^{\circ} 51^{\prime}$ & $38^{\circ} 17^{\prime}$ & 2443 & 1228 & 12.3 & 23,0 & 2 & 24 & 55 & 4.8 & 0.9 \\
\hline $\begin{array}{l}\text { Total } \\
\end{array}$ & & & & & & & & & 596 & 6741 & & \\
\hline
\end{tabular}


Adapter $(5 \mathrm{pmol} / \mu \mathrm{l})$ and to $2 \mu \mathrm{l}$ restriction-ligation mix containing $0.2 \mu \mathrm{l}$ T4-Ligase buffer (10x), $0.2 \mu \mathrm{l} \mathrm{NaCl}(0.5 \mathrm{M}), 0.1 \mu \mathrm{l} \mathrm{BSA}(1 \mathrm{mg} /$ $\mathrm{ml}), 0.08 \mu \mathrm{l} \mathrm{MseI}(10 \mathrm{U} / \mu \mathrm{l}), 0.6 \mu \mathrm{l}$ EcoRI $(10$ $\mathrm{U} / \mu \mathrm{l})$ and $0.82 \mu \mathrm{l}$ T4-Ligase $(4 \mathrm{U} / \mu \mathrm{l})$. The resultant solution was incubated at room temperature over-night ( $\sim 16$ hours). A pre-amplification PCR was run in a Peltier Thermal Cycler PTC-200 (MJ Research ${ }^{\circledR}$ ), with a total volume of $15 \mu \mathrm{l}$ containing $7.8 \mu \mathrm{l}$ HPLC $\mathrm{H}_{2} \mathrm{O}$ (high performance liquid chromatography water), $1.7 \mu \mathrm{l} \mathrm{PCR}$ buffer (10x), $1 \mu \mathrm{l}$ dNTPs $(2.5 \mathrm{mM})$, $0.25 \mu \mathrm{l}$ of the pre-selective primer MO3 with selective nucleotide $\mathrm{G}(5 \mathrm{pmol} / \mu \mathrm{l}), 0,20 \mu \mathrm{l}$ of EO1 with selective nucleotide A $(5 \mathrm{pmol} / \mu \mathrm{l})$, $0.06 \mu \mathrm{l}$ Taq polymerase (Qiagen $\left.{ }^{\circledR}\right)(5 \mathrm{U} / \mu \mathrm{l})$ and $4 \mu \mathrm{l}$ of the restriction-ligation reaction (diluted 1:4). The pre-amplification PCR profile was $15 \mathrm{~min}$. at $72{ }^{\circ} \mathrm{C}$, followed by 20 cycles of $10 \mathrm{~s}$ denaturation at $94{ }^{\circ} \mathrm{C}, 30 \mathrm{~s}$ annealing at 56 ${ }^{\circ} \mathrm{C}$ and $2 \mathrm{~min}$. extension at $72{ }^{\circ} \mathrm{C}$, with a final extension step of $30 \mathrm{~min}$. at $60{ }^{\circ} \mathrm{C}$. A selective amplification was run with a total volume of 15 $\mu \mathrm{l}$ containing $8.11 \mu \mathrm{l} \mathrm{HPLC} \mathrm{H}_{2} \mathrm{O}, 1.6 \mu \mathrm{l}$ PCR buffer (10x), 0.4 $\mu \mathrm{l}$ dNTPs $(2.5 \mathrm{mM}), 0.6 \mu \mathrm{l}$ M67-Primer with selective nucleotides GCA ( $5 \mathrm{pmol} / \mu \mathrm{l}), 0.25 \mu \mathrm{l}$ E41-Primer with selective nucleotides AGG (5 pmol/ $\mu \mathrm{l}), 1.0 \mu \mathrm{MgCl}_{2}$ $(25 \mathrm{mM}), 0.06 \mu \mathrm{l}$ Taq polymerase (Qiagen $\left.{ }^{\circledR}\right)$ (5 U/ $\mu \mathrm{l})$, and $3 \mu \mathrm{l}$ pre-amplification product (diluted 1:10). The selective PCR profile was 15 min. initial denaturation at $94{ }^{\circ} \mathrm{C}$, followed by 9 cycles of $30 \mathrm{sec}$. denaturation at $94{ }^{\circ} \mathrm{C}$, $30 \mathrm{~s}$ annealing at $65{ }^{\circ} \mathrm{C}$ (reduced by $1{ }^{\circ} \mathrm{C}$ per cycle) and $2 \mathrm{~min}$. extension at $72{ }^{\circ} \mathrm{C}$, followed by 24 cycles of $30 \mathrm{~s}$ denaturation at $94{ }^{\circ} \mathrm{C}, 30$ $\mathrm{s}$ annealing at $56^{\circ} \mathrm{C}$ and $2 \mathrm{~min}$. extension at 72 ${ }^{\circ} \mathrm{C}$, with a final extension of $10 \mathrm{~min}$ at $72{ }^{\circ} \mathrm{C}$. Aliquots of the selective amplification products were diluted (1:5) before electrophoretic separation. Two $\mu$ l diluted selective PCR product was added to $12 \mu \mathrm{l} \mathrm{HiDi}$ formamide dye containing $\sim 0.02 \mu$ internal size standard (GS ROX 500, Applied Biosystems $\left.{ }^{\circledR}\right)$, denaturated for two minutes at $90^{\circ} \mathrm{C}$, immediately cooled on ice, and separated on a capillary sequencer ABI 3100 Genetic Analyser (Applied Biosys6 tems $($ )).

Eighteen primer combinations (made up of four primers for EcoRI adapters and six primers for MseI adapters) were tested in different sets. The primer combination E41-M67 (5'-FAM-GAC TGC GTA CCA ATT CAG G-3', 5-GAT GAG TCC TGA GTAAGC A -3', respectively) showed a well-resolved banding pattern and a high degree of polymorphism. A total of 596 individuals (23-24 per population) were genotyped with this combination. Reproducibility tests were conducted on 15 samples randomly selected from each run. For these 15 samples, the whole AFLP procedure was done twice (restriction ligation, pre-selective and selective amplification). Only 100 percent reproducible loci were considered in the final analysis, resulting in 106 putative loci. Furthermore, three standard lanes, two containing the same individuals and one holding a negative control were run on each plate to compare the data from different runs and to check for the mobility of fragments.

\section{Data analysis}

Data were aligned with the internal size standard using GENESCAN 3.7 and fragments were scored with GENOTYPER 3.7 (Applied Biosystems $\left.{ }^{\circledR}\right)$. Fragments with sizes ranging from 50-500 nucleotides (bp) were scored as present (1) or absent (0) and transformed to a 1/0 matrix. Each fragment was controlled and edited manually. Overall and gender-segregated genetic diversity (estimated as total diversity $\left(H_{\mathrm{t}}\right)$, within-population diversity $\left(H_{\mathrm{e}}\right)$ and among-population diversity $\left.\left(H_{\mathrm{b}}\right)\right)$, percentage of polymorphic loci (PPL) at the 5 percent level, and coefficient of differentiation among-populations $\left(F_{\mathrm{ST}}\right)$ were computed using AFLP-SURV (Vekemans et al. 2002, available at http://www.ulb.ac.be/sciences/lagev/) following a Bayesian method with non-uniform prior distribution of allele frequencies (Zhivotovsky 1999). Gene flow $\left(\mathrm{N}_{\mathrm{m}}\right)$ was estimated using the formula: $N m=\left(1-\mathrm{F}_{\mathrm{ST}}\right) / 4 \mathrm{~F}_{\mathrm{ST}}$ (Slatkin \& Barton 1989). Hardy-Weinberg equilibrium 
was assumed in all computations. Partition of genetic diversity and the significance of the differences within and among-populations and different groups were estimated by an analysis of molecular variance (AMOVA) using ARLEQUIN Version 3.0 based on AFLP phenotypes (Excoffier et al. 2005; http://cmpg.unibe. ch/software/arlequin 3 ). The different groups of the sampled populations that are used to examine the partitioning of genetic diversity are provided in Supporting Information 1. The fine-scale spatial autocorrelation analysis for 21 natural populations was performed with SPAGeDi 1.2 (Hardy \& Vekemans 2002) using pairwise kinship coefficients $\left(\mathrm{F}_{\mathrm{ij}}\right)$ between individuals plotted against pairwise distances (Hardy, 2003). The inbreeding coefficient is assumed to be 0 (as for dioecious species) following Hardy et al. (2006) and Tero et al. (2005). The significance of the spatial genetic structure (SGS) was tested by upper and lower bounds of the 95 percent confidence interval of $\mathrm{F}_{\mathrm{ij}}$ defined after 10,000 random permutations of individuals among geographic locations. Eight distance classes were determined for all populations with one exception (DK, set to 4 classes) after series of tests in order to obtain a minimum of 30 pairs of individuals that lie within a given distance interval. The program NTSYS-pc 2.0 (Rohlf 1998) was used to calculate an UPGMA (Unweighted Pair Group Method with Arithmetic mean) tree to visualize genetic distances between populations. Additionally, a Mantel test was performed to examine the correlation between geographic and genetic distances. The Spearman's nonparametric correlation (Spearman 1907) was used to test for associations between genetic diversity and population size, tree density, distance from the putative original population (Bonga forest), and distance from the nearest population.

\section{Results}

\section{Within population genetic diversity}

The AFLP analysis of 596 samples from 25 populations of $H$. abyssinica resulted in a total of 106 unambiguously scorable putative markers in the range from 52 to 496 bps of which $97(91.5 \%)$ were polymorphic. The percentage of polymorphic loci (PPL) within-populations ranged from 29.9 percent at Dodola Serofta (farmland/homestead population with a size of $\mathrm{N}=75$ ) and Uraga (located in a very small forest, $\mathrm{N}=70$ ) to 90.7 percent at Dinsho (located in a well-protected Park Forest, $\mathrm{N}=260$ ). Varying genetic diversities were observed at AFLP loci ranging from 0.139 at Dodola-Serofta to 0.362 at Dinsho with a mean genetic diversity of $H_{\mathrm{e}}=0.195$ (Table 2, 3). The largest remaining population $\mathrm{DD}(\mathrm{N} \approx 5000)$ showed only a moderate genetic diversity $\left(H_{\mathrm{e}}=0.173\right.$, PPL $=36.1 \%$ ). On the other hand, population DK with only 26 remaining individuals showed comparatively high levels of genetic diversity $\left(H_{\mathrm{e}}=0.217\right.$, PPL $\left.=45.4 \%\right)$. In general, closed forest populations harbored slightly more genetic diversity (mean $\left.\mathrm{H}_{\mathrm{e}}=0.207\right)$ than woodland (mean $\mathrm{H}_{\mathrm{e}}=0.190$ ) and farmland (mean $\mathrm{H}_{\mathrm{e}}=0.172$ ) populations.

The planted populations harboured slightly different mean genetic diversities from their putative seed sources $\left(\mathrm{H}_{\mathrm{e}}\right.$ of $\mathrm{DK}=0.217, \mathrm{H}_{\mathrm{e}}$ of $\mathrm{DKP}=0.226 ; \mathrm{H}_{\mathrm{e}}$ of $\mathrm{SM}=0.170, \mathrm{H}_{\mathrm{e}}$ of $\mathrm{SMP}=$ $0.146)$. The planted population DKP contained slightly higher genetic diversity than its putative parent population DK probably due to sampling bias and infusion of pollen to the putative parent population from external sources. On the other hand, the plantation SMP exhibited lower genetic diversity than its putative parent population SM most likely due to sampling bias.

There was no association between genetic diversity and actual population size (Spearman's nonparametric correlation $\mathrm{r}=-0.208$, $\mathrm{p}$ $=0.353)$. Even though there are marked dif- 
Table 2 Summary of within-populations genetic diversity and spatial genetic structure in $H$. abyssinica populations. The populations are sorted north to south.

\begin{tabular}{|c|c|c|c|c|c|c|c|c|c|}
\hline $\begin{array}{l}\text { Popula- } \\
\text { tion } \\
\text { code }\end{array}$ & $\begin{array}{l}\text { Type of } \\
\text { forest }\end{array}$ & Stand type & $\mathrm{PPL}^{\mathrm{a}}$ & $\mathrm{H}_{\mathrm{e}}^{\mathrm{b}}$ & $\begin{array}{l}\text { Densi- } \\
\text { ty } \\
\text { (ind/ha) }\end{array}$ & $\begin{array}{l}\text { Max } \\
F(d)^{c}\end{array}$ & $\begin{array}{l}\text { Max } \\
\text { distance }\end{array}$ & $\begin{array}{l}\text { Distance } \\
\text { classes }^{\mathrm{d}}\end{array}$ & $\begin{array}{l}\text { Distance }(\mathrm{km}) \\
\text { from nearest } \\
\text { population }\end{array}$ \\
\hline $\mathrm{DK}$ & woodland & Pure Hagenia & 45.4 & 0.217 & 16 & 0.19 & 36 & 1 & $215.0(\mathrm{WD})$ \\
\hline DKP & plantation & plantation & 47.4 & 0.226 & na & na & na & na & na \\
\hline KDP & plantation & plantation & 39.2 & 0.183 & na & na & na & na & na \\
\hline WD & woodland & $\begin{array}{l}\text { Hagenia- } \\
\text { dominated } \\
\text { mixed }\end{array}$ & 43.3 & 0.194 & na & na & na & na & na \\
\hline KB & $\begin{array}{l}\text { Closed } \\
\text { forest }\end{array}$ & $\begin{array}{l}\text { Hagenia- } \\
\text { dominated } \\
\text { mixed }\end{array}$ & 45.4 & 0.206 & 52 & 0.06 & 15 & $1-2$ & $141.2(\mathrm{WB})$ \\
\hline DR & $\begin{array}{l}\text { Closed } \\
\text { forest }\end{array}$ & $\begin{array}{l}\text { Mixed, sparse } \\
\text { Hagenia }\end{array}$ & 39.2 & 0.189 & 12.5 & ns & ns & & 131.7 (WD) \\
\hline WB & $\begin{array}{l}\text { Closed } \\
\text { forest }\end{array}$ & $\begin{array}{l}\text { Hagenia- } \\
\text { dominated } \\
\text { mixed }\end{array}$ & 43.3 & 0.211 & 75.7 & ns & ns & & $141.2(\mathrm{~KB})$ \\
\hline WW & woodland & $\begin{array}{l}\text { Hagenia- } \\
\text { dominated } \\
\text { mixed }\end{array}$ & 41.2 & 0.189 & 5.4 & ns & ns & & $141.7(\mathrm{DN})$ \\
\hline $\mathrm{CM}$ & $\begin{array}{l}\text { Closed } \\
\text { forest }\end{array}$ & $\begin{array}{l}\text { Mixed, sparse } \\
\text { Hagenia }\end{array}$ & 37.1 & 0.192 & 17.8 & 0.09 & 31.6 & $1-3$ & 98.8 (ZQ) \\
\hline $\mathrm{DN}$ & $\begin{array}{l}\text { Closed } \\
\text { forest }\end{array}$ & $\begin{array}{l}\text { Mixed, sparse } \\
\text { Hagenia }\end{array}$ & 48.5 & 0.212 & 13.9 & ns & ns & & $136.3(\mathrm{CL})$ \\
\hline ZQ & $\begin{array}{l}\text { Closed } \\
\text { forest }\end{array}$ & $\begin{array}{l}\text { Mixed, sparse } \\
\text { Hagenia }\end{array}$ & 45.4 & 0.205 & 0.7 & ns & ns & & $78.3(\mathrm{CL})$ \\
\hline $\mathrm{BB}$ & $\begin{array}{l}\text { Closed } \\
\text { forest }\end{array}$ & $\begin{array}{l}\text { Mixed, sparse } \\
\text { Hagenia }\end{array}$ & 44.3 & 0.213 & 27.8 & 0.07 & 18 & 1 & $122.2(\mathrm{CM})$ \\
\hline CL & woodland & $\begin{array}{l}\text { Hagenia- } \\
\text { dominated } \\
\text { mixed }\end{array}$ & 37.1 & 0.177 & 7.1 & 0.08 & 80 & $1-2$ & $61.4(\mathrm{MS})$ \\
\hline SMP & plantation & plantation & 33.0 & 0.146 & na & na & na & na & na \\
\hline SM & $\begin{array}{l}\text { Closed } \\
\text { forest }\end{array}$ & $\begin{array}{l}\text { Mixed, sparse } \\
\text { Hagenia }\end{array}$ & 38.1 & 0.170 & 23.8 & ns & ns & & $69.3(\mathrm{BG})$ \\
\hline MS & $\begin{array}{l}\text { Closed } \\
\text { forest }\end{array}$ & $\begin{array}{l}\text { Mixed, sparse } \\
\text { Hagenia }\end{array}$ & 49.5 & 0.200 & 10 & ns & ns & & $28.5(\mathrm{KL})$ \\
\hline BG & $\begin{array}{l}\text { Closed } \\
\text { forest }\end{array}$ & $\begin{array}{l}\text { Hagenia- } \\
\text { dominated } \\
\text { mixed }\end{array}$ & 46.4 & 0.198 & 5 & ns & ns & & $69.3(\mathrm{SM})$ \\
\hline KL & $\begin{array}{l}\text { Wooded } \\
\text { grassland }\end{array}$ & $\begin{array}{l}\text { Hagenia- } \\
\text { dominated } \\
\text { mixed }\end{array}$ & 42.3 & 0.195 & 12.5 & 0.2 & 56 & 1 & 28.5 (MS) \\
\hline DO & $\begin{array}{l}\text { Closed } \\
\text { forest }\end{array}$ & $\begin{array}{l}\text { Hagenia- } \\
\text { dominated } \\
\text { mixed }\end{array}$ & 90.7 & 0.362 & 16.7 & 0.21 & 44 & 1 & 37.5 (RR) \\
\hline$\overline{\mathrm{DS}}$ & Farm land & Pure Hagenia & 29.9 & 0.139 & 10 & 0.12 & 64 & $1-2$ & 22.3 (DD) \\
\hline DD & $\begin{array}{l}\text { Closed } \\
\text { forest }\end{array}$ & $\begin{array}{l}\text { Hagenia- } \\
\text { dominated } \\
\text { mixed }\end{array}$ & 36.1 & 0.173 & 30.9 & ns & ns & & 22.3 (DS) \\
\hline
\end{tabular}


Table 2 (continuation)

\begin{tabular}{llllllllll}
\hline RR & Woodland & $\begin{array}{l}\text { Hagenia- } \\
\text { dominated } \\
\text { mixed }\end{array}$ & 36.1 & 0.169 & 10.5 & 0.06 & 52 & $1-2$ & 37.5 (DO) \\
\hline BR & $\begin{array}{l}\text { Wooded } \\
\text { grassland }\end{array}$ & $\begin{array}{l}\text { Hagenia- } \\
\text { dominated } \\
\text { mixed }\end{array}$ & 38.1 & 0.187 & 9.1 & ns & ns & 20.6 (UR) \\
\hline $\mathrm{UR}$ & $\begin{array}{l}\text { Closed } \\
\text { forest }\end{array}$ & $\begin{array}{l}\text { Mixed, sparse } \\
\text { Hagenia }\end{array}$ & 29.9 & 0.160 & 13.9 & $\mathrm{~ns}$ & $\mathrm{~ns}$ & 20.6 (BR) \\
\hline $\mathrm{HM}$ & Farm land & $\begin{array}{l}\text { Hagenia- } \\
\text { dominated } \\
\text { mixed }\end{array}$ & 35.1 & 0.168 & 4.8 & 0.09 & 58 & 1 & 41.0 (UR) \\
\hline
\end{tabular}

Note. Abbreviations: ${ }^{\mathrm{a} P P L}$ - percent of polymorphic loci, ${ }^{\mathrm{b}} \mathrm{H}_{e}$ - Nei's gene diversity, ${ }^{\mathrm{c}} \mathrm{F}(\mathrm{d})$ - kinship coefficient averaged over distance classes, ${ }^{\mathrm{d}}$ distance classes for populations that showed family structures are indicated, na - not available, ns - not significant.

Table 3 Summary of the mean genetic diversity and population differentiation in subdivided populations of H. abyssinica for all populations and for the two chlorotype lineages

\begin{tabular}{|c|c|c|c|c|c|c|c|c|c|c|c|c|}
\hline & \multicolumn{3}{|c|}{$H_{t}^{a}$} & \multicolumn{3}{|c|}{$H_{w}^{b}$} & \multicolumn{3}{|c|}{$H_{b}^{c}$} & \multicolumn{3}{|c|}{$F_{S T}{ }^{d}$} \\
\hline & All & $L I^{e}$ & $L I I^{f}$ & All & $L I$ & $L I I$ & All & $L I$ & $L I I$ & All & $L I$ & $L I I$ \\
\hline Mean & 0.212 & 0.206 & 0.214 & 0.195 & 0.193 & 0.197 & 0.016 & 0.013 & 0.018 & 0.077 & 0.063 & 0.083 \\
\hline Upper 99\% & limit & & & & & & & & & 0.013 & 0.013 & 0.018 \\
\hline$p$ & & & & & & & & & & 0.000 & 0.000 & 0.000 \\
\hline
\end{tabular}

Note. Abbreviations: ${ }^{a} H_{t}$ - total diversity, ${ }^{b} H_{w}$ - within-population diversity, ${ }^{c} H_{b}$ - among-population diversity, ${ }^{\mathrm{d}} F_{S T}$ - population differentiation, ${ }^{\circ} L I$ - lineage I: DK, DKP, KDP, WD, DR, WB, SM, SMP and BG populations, ${ }^{\mathrm{f}} \mathrm{LII}$ - lineage II: BB, BR, CL, CM, DD, DN, DO, DS, HM, KB, KL, MS, RR, UR, WW and ZQ populations; for population codes, see Table 1 . Upper $99 \%$ limit - value of $F_{S T}$ lying at the $1 \%$ rightmost part of the distribution under the null hypothesis, $p$ - the probability of rejecting the null hypothesis.

ferences in genetic diversity for some populations, mean genetic diversities for the two sexes are similar $\left(H_{\mathrm{e}}=0.207 \pm 0.013\right.$ for male, $H_{\mathrm{e}}=0.201 \pm 0.019$ for female). The two chloroplast lineages (see introduction) show only minor differences in mean $\left(H_{\mathrm{w}}\right)$ and total genetic diversity $\left(H_{\mathrm{t}}\right)$ at AFLPs (lineage I: $H_{\mathrm{w}}=$ 0.193 and $H_{\mathrm{t}}=0.206$, lineage II: $H_{\mathrm{w}}=0.197$ and and $H_{\mathrm{t}}=0.214$; Table 3 ).

Based on chloroplast DNA analyses, the putative entry point of $H$. abyssinica into Ethiopia during recolonization is located in the southwestern mountains of Ethiopia (Ayele et al. 2009). The recolonization routes of the species were reconstructed from southwest to the north, to the east and to the south (Ayele et al. 2009, see also Fig. 1). There was no association between distance from the putative original population and genetic diversity $\left(H_{\mathrm{e}}\right.$, PPL) of populations (Spearman's nonparamet- ric correlation $r=-0.205, p=0.186$ ) and thus no indication of loss of genetic diversity during recolonization.

\section{Partitioning of genetic diversity among pop- ulations}

High mean within-population variation $\left(H_{\mathrm{e}}=\right.$ $0.195)$ and moderate population differentiation $\left(F_{\mathrm{ST}}=0.077, p<0.001\right)$ was observed (Table $3)$. The differentiation between populations within the two chloroplast lineages (Ayele et al. 2009) was similar (lineage I: $F_{S T}=0.063 \mathrm{p}<$ 0.001 , lineage II: $\left.F_{\mathrm{ST}}=0.083, p<0.001\right)(\mathrm{Ta}-$ ble 3$)$. The estimated number of migrants per generation $\left(N_{m}\right)$ as a parameter characterizing gene flow among populations computed for all populations based on $F_{\mathrm{ST}}$ was 3 .

The analyses of molecular variance (AMOVA) performed for all populations revealed 
Table 4 Partitioning of AFLP variation among H. abyssinica individuals in Ethiopia computed by analysis of molecular variance (AMOVA)

\begin{tabular}{|c|c|c|c|c|c|}
\hline Source of variation & $d f^{a}$ & $S S^{b}$ & $V c^{c}$ & $P v^{d}$ & $L s^{e}$ \\
\hline Among-populations & 24 & 557.42 & 0.71554 & 10.40 & $* * *$ \\
\hline Within-populations & 571 & 3521.63 & 6.16748 & 89.60 & $* * *$ \\
\hline Among ecosystem groups & 4 & 89.92 & -0.00874 & -0.13 & $n s^{\mathrm{f}}$ \\
\hline Among-populations & 20 & 467.50 & 0.72178 & 10.49 & $* * *$ \\
\hline Within-populations & 571 & 3521.630 & 6.16748 & 89.64 & $* * *$ \\
\hline Among geographic groups & 3 & 105.427 & 0.09441 & 1.40 & ns \\
\hline Among-populations & 21 & 451.993 & 0.64411 & 9.30 & $* * *$ \\
\hline Within-populations & 571 & 3521.63 & 6.16748 & 89.30 & $* * *$ \\
\hline Among stand groups & 3 & 64.062 & -0.01630 & -0.24 & ns \\
\hline Among-populations & 21 & 493.358 & 0.72650 & 10.56 & $* * *$ \\
\hline Within-populations & 571 & 3521.63 & 6.16748 & 89.67 & $* * *$ \\
\hline Among tree seed zones groups & 12 & 311.133 & 0.18654 & 2.70 & ns \\
\hline Among-populations & 9 & 168.756 & 0.52310 & 7.50 & $* * *$ \\
\hline Within-populations & 502 & 3132.63 & 6.24030 & 89.8 & $* * *$ \\
\hline Among chloroplast lineage groups & 1 & 37.525 & 0.05421 & 0.78 & $*$ \\
\hline Among-populations & 23 & 519.895 & 0.68950 & 9.98 & $* * *$ \\
\hline Within-populations & 571 & 3521.630 & 6.16748 & 89.24 & $* * *$ \\
\hline Among sex groups & 1 & 3.702 & -0.08835 & -1.34 & ns \\
\hline Among-populations & 22 & 270.164 & 0.70368 & 10.64 & $* * *$ \\
\hline Within-populations & 193 & 1157.245 & 5.99609 & 90.69 & $* * *$ \\
\hline
\end{tabular}

Note. Abbreviations: ${ }^{a} d f$ - degree of freedom, ${ }^{b} S S$ - sum of squares, ${ }^{c} v c$ - variance components, ${ }^{d} p v$ - percent variation, ${ }^{e} l s$ - level of significance.

that 10.4 percent of the total variation was attributed to the differences among populations. Very low proportions of the total variation were distributed among groups representing different ecosystems, geographic regions, forest stands, tree seed zones and the two sexes (Table 4). Only differentiation among chloroplast lineages was significant but very low $(\mathrm{PV}=0.78 \%, \mathrm{p}<0.05)$. When partitioned by different groups, the level of genetic differentiation among-populations is similar ranging from 7.5 percent to 10.6 percent (Table 4). No private fragment or fragment fixed in only one population was detected.

\section{Relationships among populations}

The pairwise Nei's genetic distance matrix (Supporting Information 3) among 25 popula- tions exhibits genetic differences of less than 7 percent for each pairwise comparison. The UPGMA dendrogram calculated from Nei's genetic distances (Nei 1978) does not reflect the geographic origin of the populations (Fig. 2). Also, the planted populations DKP and SMP were not clustered with their putative parent populations DK and SM, respectively (Fig. 2). Effect of random variation due to sampling and possible infusion of pollen to the putative parent populations from external sources might explain this observation. A test of association between geographic and genetic distances (Mantel test) showed a very low and non-significant correlation $(\mathrm{r}=0.14607, \mathrm{p}=$ $0.9024)$. For example, the highest genetic distance was observed between populations RR and DO (0.0669) that are geographically close (37.5 km air distance) but separated by a big 


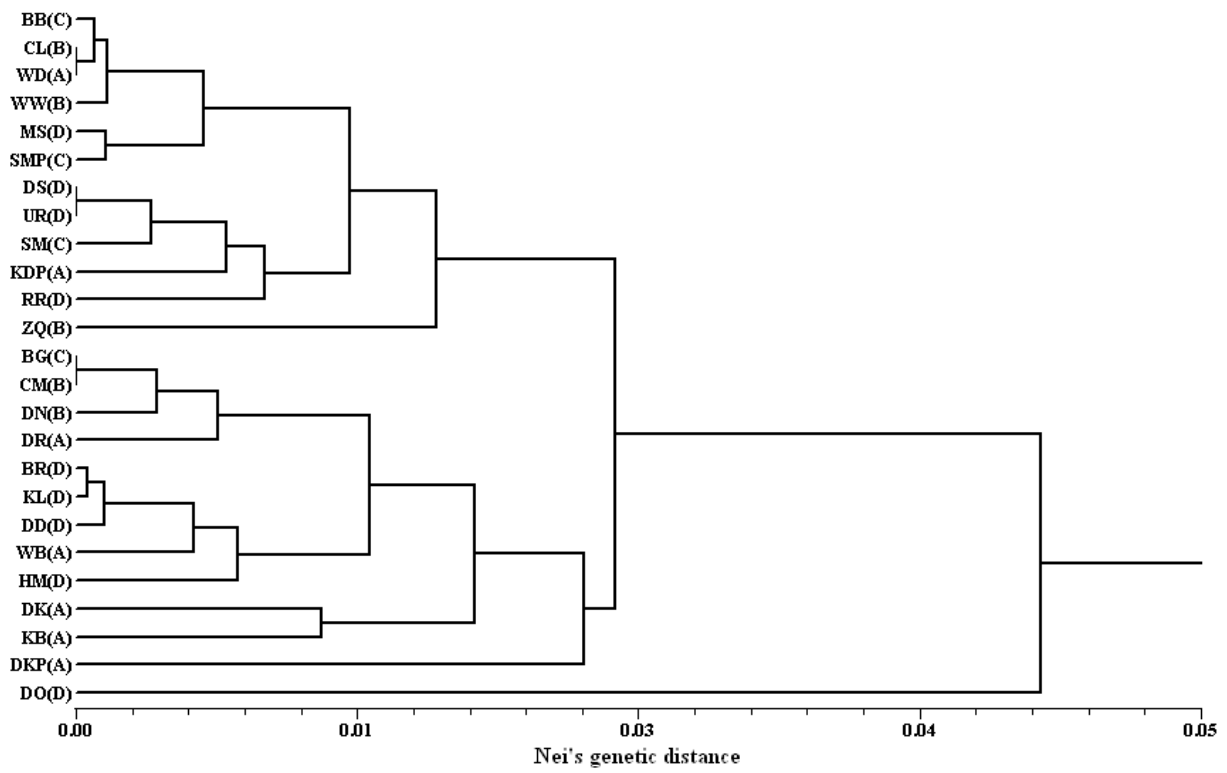

Figure 2 UPGMA tree drawn from Nei's (1978) genetic distances computed from AFLPs. Population codes follow Table 1. Letters in parenthesis designate geographic regions: A - northern region, $\mathrm{B}$ - central region, $\mathrm{C}$ - southwestern region, D - southern region.

mountain embracing the second highest peak in the country, Tulu Dimtu. On the other hand, the three pairs of populations with the lowest genetic distances (from 0 to 0.0005 ) between them (WD and WW, WD and BB and KL and BR) are widely separated $(240 \mathrm{~km}, 452 \mathrm{~km}$ and $103 \mathrm{~km}$, respectively), with some small mountains between them.

\section{Fine-scale spatial genetic structure}

In general, most populations from farmlands, wooded grasslands and woodlands (6 out of 8) showed significant spatial genetic structure up to greater distances $(36-80 \mathrm{~m})$ whereas only 4 out of 13 closed forest populations showed family structures at smaller distance classes (15-44 m) (Table 2; Supporting Information 4). No SGS was observed in the largest remaining $H$. abyssinica population (DD) in Ethiopia ( 5000 individuals) while significant SGS was observed in the second largest population DO $(\mathrm{N}=260)$, harboring the highest genetic diversity. In most (7 out of 10) of the small populations $(N=55-80)$ of the closed forest type, no SGS was observed (Table 2). Density, population size and distance from the nearest population were not associated with the kinship coefficient averaged over distance classes $\mathrm{F}(\mathrm{d})$ of 21 natural populations (for example, Spearman's nonparametric correlation coefficient $(r)$ for density $=-0.065, p=0.391)$.

\section{Discussion}

\section{Genetic diversity and population differentia- tion}

Effective gene flow through pollen and possibly seed is likely the main factor contributing to low population differentiation and varying genetic diversity within populations of $H$. $a b$ yssinica. Results confirm the first hypothesis that predicted high variation within populations and low differentiation among popula- 
tions. Feyissa et al. (2007) reported higher mean genetic diversity ( 0.30$)$ in 12 populations of $H$. abyssinica from central and southern regions of Ethiopia at 84 polymorphic ISSR markers. They also found a higher coefficient of differentiation $\left(G_{\mathrm{ST}}=0.25\right)$ than the present work. Different marker systems, fewer populations and small sample sizes in their study might have contributed to the differences from our results.

No decreasing genetic diversity was observed along recolonization routes, due to effective gene flow that counteracts effects of genetic drift (hypothesis 2). A general trend of increasing genetic diversity away from refugia was observed in European beech based on isozymes (Comps et al. 2001), suggesting a gain in genetic diversity during recolonization due to gene flow, population admixture effects and selection. Petit et al. (2003) also reported that the mixing of colonization routes and increased levels of seed flow resulted in increased intrapopulation diversity away from refugia in some European woody species at maternally inherited markers. In contrast, Lobelia giberroa, which entered Ethiopia also from the south (Kebede et al. 2007), Carpinus betulus (Betulaceae) in Europe (Coart et al. 2005) and Ptercarpus officinalis (Fabaceae) in the Caribbean (Rivera-Ocasio et al. 2002), exhibited decreasing diversity during recolonization at AFLP markers. As $H$. abyssinica is presumably a predominantly wind-pollinated canopy tree, pollen most likely disperse over long distances contributing to the maintenance of comparatively high levels of genetic diversity. This might explain the lack of association between genetic and geographic distances at AFLPs.

The observation of higher diversity in closed forests, the location of the population with highest diversity in a well-protected forest, and the observation of the lowest diversity in two farmland populations suggest human impact on populations reduced genetic diversity. Genetic diversity was not correlated with sizes of extant populations (hypothesis 2). This result 12 might be due to recent reductions of population sizes due to human impact, which did not yet diminish genetic diversity, and due to efficient gene flow among populations in the past. Phylogeographic analyses of the 25 populations at cpDNA revealed two chloroplast lineages (Ayele et al. 2009). Most likely, lineage I originated from lineage II by a deletion in a specific chloroplast region. We would expect a lower genetic diversity in populations with the derived chloroplast haplotypes of lineage I. However, lineage II exhibited only slightly higher diversity than lineage I. Also, there was no significant differentiation between chloroplast lineages at AFLPs presumably due to efficient long-distance gene flow through pollen.

\section{Comparison of genetic diversity with other species}

In her review of intraspecific genetic diversity in plant species at nuclear DNA markers, Nybom (2004) reported a slightly higher mean within-population genetic diversity $\left(H_{p o p}\right)$ of 0.22 at RAPDs, 0.23 at AFLPs and 0.22 at ISSRs than the mean genetic diversity of $H . a b$ yssinica $\left(H_{\mathrm{e}}=0.195\right)$ at AFLPs. Studies based on AFLP markers are limited to a few tropical tree species and information on the method of estimating $H_{\mathrm{e}}$ is missing in most of the cases, making comparisons difficult. The mean genetic diversity of $H$. abyssinica is moderate compared to other species for which the same method for the estimation of allele frequencies was applied (Supporting Information 5). Wider natural distribution of Cordia africana $\left(H_{\mathrm{e}}=\right.$ $0.287)$ and Juniperus procera $\left(H_{\mathrm{e}}=0.269\right)$ in Ethiopia and the effective dispersal of seeds of $C$. africana by animals most likely explain the higher diversity observed in these two species as compared to that of $H$. abysinica $\left(H_{\mathrm{e}}=\right.$ 0.195) (Supporting Information 5).

Most studies investigating genetic differentiation among populations of wind-pollinated forest trees were conducted in temperate and boreal forests. Most species investigated were of the Pinaceae and Fagaceae families, and un- 
like $H$. abyssinica, populations were typically large, more or less continuous, and characterized by high densities. Most of these genetic inventories in stand-forming, common Pinaceae (e.g. Pinus spp., Picea spp., Pseudotsuga menziesii; Lagercrantz \& Ryman 1990, Li \& Adams 1989) and Fagaceae (Fagus, Quercus; e.g. Comps et al. 2001) revealed very low differentiation (Austerlitz et al. 2000). Differentiation was higher for insect-pollinated species with a scattered distribution both in temperate (e.g. Sorbus torminalis; Demesure et al. 2000) and tropical (e.g. Shorea spp.; Cao et al. 2006) forests (Hamrick et al. 1992). Since it is predominantly wind-pollinated, has a very scattered distribution and small populations at least in Ethiopia, $H$. abyssinica is a species with a rare combination of life history traits. The differentiation among $H$. abyssinica populations is higher in comparison to most common wind-pollinated species occurring in high density, but lower than for most insect pollinated species occurring in low density.

\section{Fine-scale spatial genetic structure}

Despite the dispersal of seed and pollen predominantly by wind, significant spatial genetic structure was observed within nearly half of the populations of $H$. abyssinica, reflecting restricted gene flow within populations. Positive values of $\mathrm{F}_{\mathrm{ij}}$ above the $95 \%$ confidence interval were found at short distances, indicating higher genetic relatedness among neighboring individuals than among random pairs of individuals, whereas negative values of $F_{i j}$ occurred at larger distances, showing isolation-by-distance within a population (Tero et al. 2005). Significant spatial genetic structure in $H$. abyssinica extends up to $80 \mathrm{~m}$. This result allows us to reject the hypothesis that predicts absence of fine-scale genetic spatial patterning in $H$. abyssinica. Even though seeds are very light, restricted dispersal of diaspores is likely to be the principal cause of spatial structures, assuming that seed dispersal in $H$. abyssinica is more restricted than pollen dispersal as in most other trees. While there was no association between tree density, population size or distance from the nearest population and the occurrence of wide-ranging SGS, significant fine-scale SGS was observed more frequently in farmlands and open woodlands as compared to closed forests.

\section{Conclusion}

Despite the relatively recent recolonization of Ethiopia by $H$. abyssinica that has been suggested by fossil pollen data and the small population sizes, the AFLP analysis detected surprisingly high genetic diversity within populations with considerable differences in $H_{\mathrm{e}}$ between populations, and low but significant genetic differentiation among populations. Since even a restricted number of migrants per generation is sufficient to counteract genetic differentiation (Wright 1931), the effect of recent recolonization is not reflected in the levels of genetic diversity. The observed variation does not reflect clinal variation patterns. Consequently, (1) only a seed zone approach is questionable to conserve genetic diversity; (2) it is difficult to capture optimal variation for conservation and tree improvement based on approaches to sample ecological and/or geographic zones without consideration of genetic variation; (3) due to significant genetic differentiation observed among populations, it is necessary to collect seeds from as many populations as possible for gene bank storage, establishment of provenance trials, establishment of ex situ conservation stands, and for forestation programs. The very high genetic diversity in some populations calls for the need to conserve the observed variability. The moderate to high intraspecific variation and a wide vertical distribution of the populations (2200 to $3200 \mathrm{~m}$ asl) may suggest that $H$. abyssinica might have occupied wider areas in the past. The extant populations, on the other hand, harbor quite high levels of genetic diversity despite of their small sizes. Nonetheless, our 
data suggest that human impact in the form of selective removal of trees conversely affects genetic diversity, as observed in the two farmland populations. In general, the investigation of genetic diversity at AFLPs covering the natural distribution range in Ethiopia enhanced our understanding of the phylogeography, genetic structure and the forces shaping genetic variation patterns in $H$. abyssinica.

Further work on the intraspecific genetic variation and palynological investigations in other African countries where $H$. abyssinica is known to grow is recommended to fully understand the recolonization history and to identify the refugia of the species. Fragmentation might have caused isolation of populations that were previously interconnected through gene flow, and it is therefore recommended to study extant gene flow in the few remaining relic populations.

\section{Acknowledgments}

This project is a component of the "Support to the Forest Genetic Resources Conservation Project" of the Ethiopian Institute of Biodiversity Conservation (IBC), supported by the German Federal Ministry of Economic Cooperation and Development (BMZ) through the German Technical Cooperation (gtz). The German Academic Exchange Service (DAAD) executed the grant. The National Meteorological Service Agency of Ethiopia provided climatic data. The laboratory work was conducted at the Forest Genetics and Forest Tree Breeding Lab, Georg-August University Göttingen, Germany. We thank Oleksandra Dolynska, Thomas Seliger and Olga Artes for kindly assisting in the laboratory and Daniel Bekele Ayele for his help during the fieldwork.

\section{References}

Austerlitz F., Mariette S., Machon N., Gouyon P-H., Godelle B., 2000. Effects of colonization processes on genetic diversity: differences between annual plants and tree species. Genetics 154:1309-1321.

Ayele T.B., Gailing O., Finkeldey R., 2011. Assessment and integration of genetic, morphological and demographic variation in Hagenia abyssinica (Bruce) J.F. Gmel to guide its conservation. Journal of Nature Conservation 19: 8-17. DOI: 10.1016/j.jnc.2010.03.001.

Ayele T.B., Gailing O., Umer M., Finkeldey R., 2009. Chloroplast DNA haplotype diversity and postglacial recolonization of Hagenia abyssinica (Bruce) J.F. Gmel in Ethiopia. Plant Systematics and Evolution 280: 175185. DOI: 10.1007/s00606-009-0177-5.

Bawa K.S., Krugman S.L., 1990. Reproductive biology and genetics of tropical trees in relation to conservation and management. In: Gomez-Pampa A., Whitmore T.C., Hadley M. (eds), Rain Forest Regeneration and Management, The Parthenon Publishing Group, pp. 119-136.

Beuning K.R.M., Talbot M.R., Kelts, K., 1997. A revised 30,000-year paleoclimatic and paleohydrologic history of Lake Albert, East Africa. Palaeogeography, Palaeoclimatology, Palaeoecology 136:259-279. DOI: 10.1016/S0031-0182(97)00034-5

Bonnefille R., Riollet G., Buchet G., Icole M., Lafont R., Arnold M., Jolly, D., 1995. Glacial/interglacial record from intertropical Africa, high resolution pollen and carbo data at Rusaka, Burundi. Quaternary Science Reviews 14:917-936. DOI: 10.1016/02773791(95)00071-2

Cao C.P., Finkeldey R., Siregar I.Z., Siregar U.J., and Gailing O., 2006. Genetic diversity within and among-populations of Shorea leprosula Miq. and Shorea parvifolia Dyer (Dipterocarpaceae) in Indonesia detected by AFLPs. Tree Genetics \& Genomes 2:225-239. DOI: 10.1007/s11295-006-0046-0

Castillo-Cárdenas M.F., Toro-Perea N., Cárdenas-Henao H., 2005. Population genetic structure of neotropical Mangrove species on the Colombian Pacific Coast: Pelliciera rhizophorae (Pellicieraceae). Biotropica 37:266273. DOI: $10.1111 / \mathrm{j} .1744-7429.2005 .00036 . x$

Cavers S., Degen B., Caron H., Lemes M.R., Margis R., Salgueiro F., Lowe A.J., 2005. Optimal sampling strategy for estimation of spatial genetic structure in tree populations. Heredity 95:281-289. DOI: 10.1038/ sj.hdy. 6800709

Coart E., Van Glabeke S., Petit R.J., Van Bockstaele E., Roldán-Ruiz I., 2005. Range wide versus local patterns of genetic diversity in hornbeam (Carpinus betulus L.). Conservation Genetics 6:259-273. DOI: 10.1007/ s10592-004-7833-7

Coart E., Vekemans X., Smulders M.J.M., Wagner I., Huylenbroeck J.V., Bockstaele E.V., Roldán-Ruiz I., 2003. Genetic variation in the endangered wild apple (Malus sylvestris (L.) Mill.) in Belgium as revealed by amplified fragment length polymorphism and microsatellite markers. Molecular Ecology 12:845-857. DOI: 10.1046/j.1365-294X.2003.01778.x

Comps B., Gömöry D., Letouzey J., Thiebaut B., Petit 
R.J., 2001. Diverging trends between heterozygosity and allelic richness during post glacial colonization in the European beech. Genetics 157:389-397.

Demesure B., Guerroué B.L., Lucchi G., Prat D., Petit R-J., 2000. Genetic variability of a scattered temperate forest tree: Sorbus torminalis L. (Crantz). Annals of Forest Science 57:63-71. DOI: 10.1051/forest:2000101

Derero A., 2007. Genetic variation in Cordia africana Lam. in Ethiopia. PhD Dissertation, Georg-August University of Göttingen.

Excoffier L., Laval G., Schneider S., 2005. Arlequin (version 3.0): An integrated software package for population genetics data analysis. Evolutionary Bioinformatics 1:47-50.

Ekramoddoullah A.K.M., Liu J.J., 2008. Molecular mapping of the Pinus monticola $\mathrm{Cr} 2$ gene using AFLP and SCAR markers. Annals of Forest Research 51: 147-148.

Feyissa T., Nybom H., Bartish I.V., Welander M., 2007. Analysis of genetic diversity in the endangered tropical tree species Hagenia abyssinica using ISSR markers. Genetic Resources and Crop Evolution 54:947-958. DOI: $10.1007 / \mathrm{s} 10722-006-9155-8$

Fichtl R., Admasu A., 1994. Honeybee flora of Ethiopia. DED - Margraf Verlag, Weikersheim.

Finkeldey R., Hattemer H.H., 2007. Tropical Forest Genetics. Springer-Verlag, Berlin. DOI: 10.1007/978-3540-37398-8

Hamrick J.L., Godt M.J.W., Sherman-Broyles S.L., 1992. Factors influencing levels of genetic diversity in woody plant species. New Forests 6:95-124. DOI: 10.1007/ BF00120641

Hardy O.J., Maggia L., Bandou E., Breyne P., Caron H., Chevallier M-H., Doligez A., Dutech C., Kremer A., Latouche-Hallé C., Troispoux V., Veron V., Degen B., 2006. Fine-scale genetic structure and gene dispersal inferences in 10 Neotropical tree species. Molecular Ecology 15:559-571. DOI: 10.1111/j.1365294X.2005.02785.x

Hardy O.J., 2003. Estimation of pairwise relatedness between individuals and characterization of isolation-by-distance processes using dominant genetic markers. Molecular Ecology 12:1577-1588. DOI: 10.1046/j.1365-294X.2003.01835.x

Hardy O.J., Vekemans X., 2002. SPAGeDi: a versatile computer program to analyse spatial genetic structure at the individual or population levels. Molecular Ecology Notes 2:618-620. DOI: 10.1046/j.14718286.2002.00305.x

Hedberg O., 1989. Rosaceae. In: Hedberg I., Edwards S. (eds), Flora of Ethiopia, Vol. 3, Pittosporaceae to Arralaceae. Addis Abeba, Ethiopia.

Hoffmann A.A., Blows M.W., 1994. Species borders: ecological and evolutionary perspectives. Trends in Ecology \& Evolution 9:223-227. DOI: 10.1016/01695347(94)90248-8

Huh M.K., Huh H.W., Back K., 2005. Genetic diversity and population structure of Acanthopanax sessiliflorus (Araliaceae) using AFLP. Korean Journal of Genetics
27:71-79.

Jump A.S., Peñuelas J., 2007. Extensive spatial genetic structure revealed by AFLP but not SSR molecular markers in the wind-pollinated tree, Fagus sylvatica. Molecular Ecology 16:925-936. DOI: 10.1111/j.1365294X.2006.03203.X

Kebede M., Ehrich D., Taberlet P., Nemomissa S., Brochmann C., 2007. Phylogeography and conservation genetics of a giant lobelia (Lobelia giberroa) in Ethiopian and Tropical East African mountains. Molecular Ecology 16:1233-1243. DOI: 10.1111/j.1365294X.2007.03232.x

Kumilign A., 2005. Estimation of sex-related genetic diversity of Hagenia abyssinica (Bruce) J.F. Gmel. M.Sc. Dissertation, Addis Ababa University.

Lagercrantz U., Ryman N., 1990. Genetic structure of Norway spruce (Picea abies): concordance of morphological and allozymic variation. Evolution 44:38-53. DOI: $10.2307 / 2409523$

Lara-Gomez G., Gailing O., Finkeldey R., 2005. Genetic variation in isolated Mexican populations of the endemic maple Acer skutchii Rehd. Allgemeine Forst und Jagdzeitung 176:97-103.

Li P., Adams W.T., 1989. Range-wide patterns of allozyme variation in Douglas-fir (Pseudotsuga menziesii). Canadian Journal of Forest Research 19:149-161. DOI: 10.1139/x89-022

Loveless M.D., Hamrick J.L., 1984. Ecological determinants of genetic structure in plant populations. Annual Review of Ecology and Systematics 15:65-95. DOI: 10.1146/annurev.es.15.110184.000433

Luu H.T., 2005. Genetic variation and the reproductive system of Dipterocarpus cf. PhD Dissertation, Georg-August University of Göttingen.

Negash L., 1995. Indigenous trees of Ethiopia: biology, uses and propagation techniques. SLU, Reprocentralen, Umeå.

Nei M., 1987. Molecular evolutionary genetics. Columbia University Press.

Nei M., 1978. Estimation of average heterozygosity and genetic distance from a small number of individuals. Genetics 89:583-590.

Nybom H., 2004. Comparison of different nuclear DNA markers for estimating intraspecific genetic diversity in plants. Molecular Ecology 13:1143-1155. DOI: 10.1111/j.1365-294X.2004.02141.x

Olago D.O., Street-Perrott F.A., Perrott R.A., Ivanovich M., Harkness D.D., 1999. Late quaternary glacial-interglacial cycle of climatic and environmental change on Mount Kenya. Journal of African Earth Science 29:593618. DOI: 10.1016/S0899-5362(99)00117-7

Petit R.J., Aguinagalde I., De Beaulieu J-L., Bittkau C., Brewer S., Cheddadi R., Ennos R., Fineschi S., Grivet D., Lascoux M, Mohanty A., Müller-Starck G., Demesure-Musch B., Palmé A., Martín P.J., Rendell S., Vendramin G.G., 2003. Glacial refugia: hotspots but 
not melting pots of genetic diversity. Science 300:15631565. DOI: $10.1126 /$ science. 1083264

Rivera-Ocasio E., Aide T.M., Mcmillan W.O., 2002. Patterns of genetic diversity and biogeographical history of the tropical wetland tree, Pterocarpus officinalis (Jacq.), in the Caribbean basin. Molecular Ecology 11:675-683. DOI: 10.1046/j.1365-294X.2002.01476.x

Rohlf F.J., 1998. NTSYS-pc: Numerical taxonomy and multivariate analysis system (Version 2.0). State University of New York, USA.

Sertse D., Gailing O., Eliades N-G., Finkeldey R., 2010. Anthropogenic and natural causes influencing population genetic structure of Juniperus procera Hochst. ex Endl. in the Ethiopian highlands. Genetic Resources and Crop Evolution doi: 10.1007/s10722-010-9623-z. DOI: $10.1007 / \mathrm{s} 10722-010-9623-\mathrm{Z}$

Slatkin M., Barton N.H., 1989. A comparison of three indirect methods for estimating average levels of gene flow. Evolution 43:1349-1368. DOI: 10.2307/2409452

Spearman C., 1907. Demonstration of formulae for true measurement of correlation. American Journal of Psychology 18:161-169. DOI: 10.2307/1412408

Tang T., Zhong Y., Jian S.G., Shi S.H., 2003. Genetic diversity of Hibiscus tiliaceus (Malvaceae) in China assessed using AFLP markers. Annals of Botany 92:409414. DOI: $10.1093 / \mathrm{aob} / \mathrm{mcg} 156$

Tero N., Aspi J., Siikamäki P., Jäkäläniemi A., 2005. Local genetic population structure in an endangered plant species, Silene tatarica (Caryophyllaceae). Heredity 94:478-487. DOI: 10.1038/sj.hdy.6800642

Umer M., Lamb H.F., Bonnefille R., Lézine A-M., Tiercelin J-J., Gibert E., Gazet J-P., Watrin J., 2007. Late Pleistocene and Holocene vegetation history of the Bale Mountains, Ethiopia. Quaternary Science Reviews 26:2229-2246. DOI: 10.1016/j.quascirev.2007.05.004

Vasilyeva G., Semerikov V., 2014. Application of amplified fragment length polymorphisms markers to study the hybridization between Pinus sibirica and P. pumila. Annals of Forest Research 57(2): 175-180.

Vekemans X., Beauwens T., Lemaire M., Roldan-Ruiz I. 2002. Data from amplified fragment length polymorphism (AFLP) markers show indication of size homoplasy and a relationship between degree of homoplasy and fragment size. Molecular Ecology 11:139-151. DOI: 10.1046/j.0962-1083.2001.01415.x

Vekemans X., Hardy O.J., 2004. New insights from fine-scale spatial genetic structure analyses in plant populations. Molecular Ecology 13:921-935. DOI: 10.1046/j.1365-294X.2004.02076.x

Vos P., Hogers R., Bleeker M., Reijans M., Lee Th Van Der Hornes M., Frijters A., Pot J., Peleman J., Kuiper M., Zabeau M., 1995. AFLP: a new technique for DNA fingerprinting. Nucleic Acids Research 23:4407-4414.
DOI: $10.1093 /$ nar/23.21.4407

White T.L., Adams W.T., Neale D.B., 2007. Forest Genetics. CABI Publishing, Wallingford and Cambridge. DOI: $10.1079 / 9781845932855.0000$

Wright S. 1969. Evolution and the genetics of populations. Vol. 2. The theory of gene frequencies. University of Chicago Press, Chicago.

Wright S., 1931. Evolution in Mendelian populations. Genetics 16:97-159.

Yeh F.C., 2000. Population Genetics. In: Young A., Boshier D., Boyle T., (eds), Forest conservation genetics: principles and practice. CABI Publishing.

Zhivotovsky L.A., 1999. Estimating population structure in diploids with multilocus dominant DNA markers. Molecular Ecology 8:907-913. DOI: 10.1046/j.1365294x.1999.00620.x

\section{Supporting Information}

The online version of the article includes Supporting Information:

Supp. Info. 1. The grouping of the sampled $H$. abyssinica populations that were used to examine the partitioning of genetic diversity at AFLP loci.

Supp. Info. 2. A female Hagenia tree demonstrating a very good quality timber from Uraga population, South Ethiopia.

Supp. Info. 3. Pairwise matrix showing Nei's genetic distance among 25 populations of $H$. abyssinica from Ethiopia.

Supp. Info. 4. Correlograms showing kinship coefficient $(\mathrm{F}(\mathrm{d}))$ averaged over distance classes and plotted against the maximum distances of 8 distance classes from AFLPs of 21 natural populations of Hagenia abyssinica.

Supp. Info. 5. Comparison of the genetic diversity of $H$. abyssinica with other species at AFLPs. 